\title{
Women and Money: Unique Issues - Selecting Your Financial Professional Team ${ }^{1}$
}

\author{
Brenda C. Williams, Diann Douglas, Martie Gillen, and Lynda Spence ${ }^{2}$
}

Societal dynamics and their effects on gender roles and family structures underscore a distinct need for financial management education to address the unique issues that women may encounter. This series of EDIS publications, "Women and Money: Unique Issues," encompasses financial management for women across the life cycle and through family transitions. This series focuses on the changes women may encounter throughout their lives and the impact of these changes on their economic status. For the rest of the publications in the series, see http://edis.ifas. ufl.edu/topic_series_women_and_money_unique_issues.

\section{Introduction}

On your road to building wealth, you may choose to engage financial professionals for guidance. Seeking out professional advice will include fees and expenses, so use care when selecting the appropriate services.

There is a variety of financial professionals to choose from, including financial planners, investment specialists, accountants, attorneys, insurance agents, and bankers. Understanding the roles, expertise, and credentials of these individuals can help you select the most appropriate individual or team for your specific financial needs.

\section{Professionals Who Can Help}

Credentials alone do not ensure a financial professional's competence, but they do provide a starting point for comparing skills and assumed knowledge in given areas. Listed below is a variety of professionals you can consider to assist with your specific financial goals.

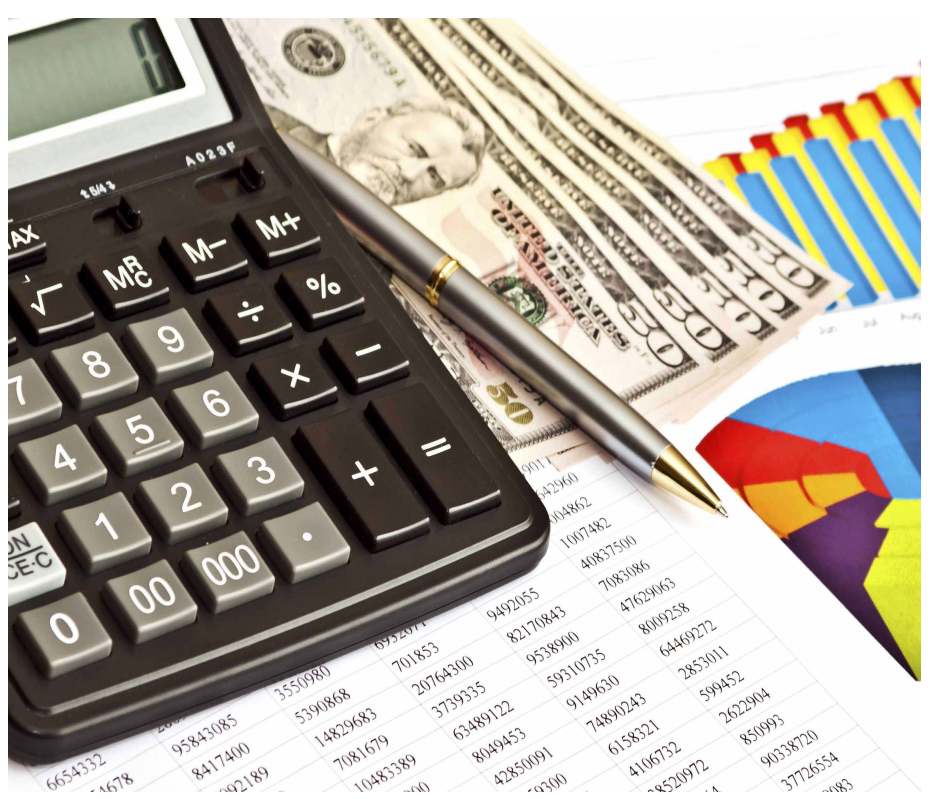

Figure 1. Before you retain the services of a financial professional, you should understand the differences between financial planners, accountants, attorneys, and investment specialists. Always make sure you choose a financial professional you trust. Credits: iStockphoto

1. This document is FCS7252, one of a series of the Department of Family, Youth and Community Sciences, UF/IFAS Extension. Original publication date: July 2013. Please visit the EDIS website at http://edis.ifas.ufl.edu.

2. Brenda C. Williams, Extension agent IV, UF/IFAS Extension Alachua County; Diann Douglas, Extension agent IV, UF/IFAS Extension Madison County; Martie Gillen, assistant professor and Family and Consumer Economics for Older Adults specialist, Department of Family, Youth and Community Sciences; and Lynda Spence, Extension faculty, UF/IFAS Extension Marion County; UF/IFAS Extension, Gainesville, FL 32611. 


\section{Financial Planner}

A financial planner takes an extensive look at your lifestyle and goals to help you create a plan to invest, save, and use your money in the best way possible. They are trained to deal with your total financial picture, including risk management, investments, tax planning, retirement planning, and estate planning. Whether you are saving for your children's college education, purchasing a home, or starting a retirement fund, a financial planner can help you develop a specific plan for your needs. A financial planner can earn a number of different certifications (Brennan and O'Neil 2009; Chan and Sweedler 2013):

- Certified Financial Planner ${ }^{\circledast}$ CFP $\left.^{\circledast}\right)$ - This designation is awarded by the Certified Financial Planner Board of Standards to individuals who meet established education, examination, and experience requirements. Individuals must also participate in annual continuing education to maintain this designation (CFP Board 2013).

- Chartered Financial Consultant (Ch. FC) - Awarded by the American College, this designation requires college courses in all aspects of financial planning. An examination process is not included but experience and continuing education are required. Similar to the CFP, those with this designation should be able to provide advice in all areas of financial planning but may advertise specialty areas.

- NAPFA Registered Agent - This designation is awarded by the National Association of Professional Advisors.

These individuals are required to take fewer college financial credits. There is no examination, but continuing education is required. They provide comprehensive, fee-only financial planning.

- Accredited Financial Counselor (AFC) - This designation is awarded by the Association of Financial Counseling and Planning Education. Debt and money management are their emphasized areas of expertise. This designation does not require as many college courses as the previous two designations (Chartered Financial Consultant and NAPFA Registered Agent).

\section{Accountant}

Accountants can prepare taxes and give advice on investment, retirement, and estate tax planning. Because accountants are skilled in understanding the tax codes, their expertise is helping to minimize your yearly tax bill. A general accountant is licensed and can prepare taxes, but is not allowed to represent you in an IRS audit. Types of accountants also include the following:
- Certified Public Accountant (CPA) - Individuals earn this designation after passing an exam in their state. CPAs are knowledgeable in income and estate tax planning and preparation. Continuing education is a requirement to maintain the certification.

- Personal Financial Specialist (PFS) - The PFS is a designation awarded by the American Institute of Certified Public Accountants. Individuals must possess a current CPA license and belong to the association. Continuing education is required to maintain the designation. Their emphasis is usually personal financial planning.

\section{Attorney}

Attorneys give advice on legal issues, including property sales, adoption, or divorce settlements. Attorneys often specialize in a specific area of the law. For example, a lawyer specializing in estate and tax planning can help prepare wills and trusts, handle probate after a spouse's death, distribute family assets, and assist with other estate planning details. Most attorneys do not have expertise in investments and will not give advice on such matters. Check with the Florida Bar Association (850-561-5600 or http://www.floridabar.org/) to locate an attorney with the required expertise.

Attorneys may charge an hourly rate or a flat fee. Before you retain an attorney, be sure to ask about the cost and what is included. If you are dealing with a legal matter, the services of a well-qualified professional are usually worth the expense.

\section{Investment Specialists}

This category includes several types of professionals. They provide services related to buying and selling stocks, bonds, mutual funds, and insurance. A full-service firm has research departments that provide current information to help investment specialists offer you the best advice. You commonly go for scheduled appointments to review your portfolio and receive updates on recommended changes.

On the other hand, discount brokers provide services at a much lower commission, but offer little assistance in analyzing market information. If you use this type of service, you have to perform the research and make decisions to buy or sell.

Investment specialists usually are one of the following (Chan and Sweedler 2013):

- Chartered Financial Analyst ${ }^{\oplus}\left(\mathbf{C F A}^{\oplus}\right)$ - This designation is awarded by the Chartered Financial Analyst Institute. 
It indicates the individual has attained a college degree, passed additional courses with exams, and has experience with investments often as a portfolio manager and investment analysis.

- Registered Investment Adviser (RIA/IAR) - The RIA may be a firm or individual. The IAR is an investment advisor representative covered by the firm's RIA. Depending on the value of the assets under management, this designation is either acquired by registration with the U.S. Securities and Exchange Commission (SEC) (more than $\$ 25$ million) or by registration with the state (less than $\$ 25$ million). Some states require that IAR's pass the NASAA Series 65 exam.

- Registered Representative (broker of broker-dealer) This is the professional often referred to as a stockbroker. The designation is awarded by the Financial Industry Regulatory Authority (FINRA). The representative sells investments and must hold either a Series 6 or 7 license. Continuing education is required to maintain this designation.

- Chartered Life Underwriter - This is a designation awarded by the American College for the individual to sell life insurance (which often has an investment component). Individuals must take college classes focused on insurance, have experience, and take continuing education courses. An insurance license may also be obtained from the state after meeting examination requirements. Again, continuing education is required to maintain the license.

Banks may also be a source of investment and related services.

- Certified Trust and Financial Advisor (CTFA) - This designation is determined by an examination conducted by the Institute of Certified Bankers. Such individuals can provide services related to individual trusts, estates, guardianship, and individual management accounts. Continuing education is required.

\section{Making a Selection}

Whether looking to hire an accountant, stockbroker, or financial planner, start by asking people you know for names of professionals they may have used. A good rule of thumb is to interview three people. Ask for the details of the service and the costs.

Ask for references and check the person's background. How long has the professional been in the industry? At what capacity? What professional associations does he or she belong to? Has he or she earned awards of distinction? Do you feel comfortable talking and interacting with the person? Does the professional clearly communicate so that you understand?

A rule of thumb is if you can explain to someone else what the individual explained to you, he or she was successful in getting his or her points across. You do not want someone who glosses over the concept and convinces you to leave the details to the expert. You want to be a full participant, so you can make sound decisions based on the information provided. The professional you hire should educate you about the subject and want your knowledge to grow as you work together.

\section{Professional Advice Costs Money}

A common concern some people have is that professional financial services cost a significant amount of money. You will pay for professional expertise and advice, but if you carefully select someone who gives you good service, it is money well spent. Consider the situation this way, you pay for many services you don't have the skills to do yourself-for example, car repairs, haircuts, and medical exams. So why be concerned about paying for sound financial guidance? Being an informed consumer and doing your homework help you select the professionals who best fit your needs.

When interviewing a potential advisor, ask about the cost of the service, including fees, commission, and how you will be billed. Some professionals may charge an hourly rate; others may charge a fee for service or commission on the sale of products you buy. Some may accept monthly payments over a period of time, while others may want the total bill paid at the time of service.

Get the information up front before you decide to retain any service (Brennan and O’Neil 2009).

\section{Conclusion}

Sometimes in your life you need to visit professionals for advice and services-whether visiting a doctor for your health, a lawyer for legal counsel, or a mechanic for car repairs. The situation is no different when it comes to your money. Financial planners, accountants, and stockbrokers can provide professional services that help you with personal finances. Don't be afraid to consult professionals and hire them as you work toward achieving your financial goals. 


\section{References}

Brennan, P., and B. O’Neil. 2009. Money Talk: A Financial Guide for Women. Ithaca, NY: Cornell University Natural Resources, Agriculture, and Engineering Services.

Chan, K., and K. Sweedler. 2013. Choosing a Financial Professional. University of Illinois Extension. http://web. extension.illinois.edu/financialpro/.

CFP Board. 2013. How to Choose a Planner. Washington, DC: Certified Financial Planner Board of Standards. http:// www.cfp.net/. 